面積や設備に制限がある場のユーザ側の意見として貫重 な報告あるとコメントがあった。今後メーカ指定の設備 で使用の同一機種間で故障率等䦙題点が垍加しないか継： 続した研究を布望したい．41番は同様のテーマによる研 究報告が過去にあり，ビームハードニングによるエネル ギーの変動. CT 固有の問題(フィルタ関数，スライス厚， 散乱線その他)。被写体の大きさ，位置依存性の補正及 び同一部位を 2 向 scan するので，体動の影響などが指 摘され, 臨床応用の場合 CT 值が補償されない限り定量 解析は問題が多いとさていた。演者等は央效エネルギー の決定は半佂層測定法で求好た值を用い，塩化ナトリウ 么水溶液に㧍ける相関は 0.9987 と非常に高く, CT 值之 奏效電子密度は，直線関係にあると報告した。田宮（名 占屋大学) 加ら, hemochromatosis に括方鉄分の定量 測定を Dual Energy Scanning 法で行なえるか又，その 場合の検出可能限界はどれ位いか質問があり，D.E.S 法 で定舅可能という判断で実験を始めた。臨床灾用は現在 研究中で今後の課題之答えた.今後前記問題点を究明, 臨床面で精度の高い笑験式を求めてほしい.42番は部空 間分解能領域を強調するため，アルゴリズムの改良と検 出器機棈の精密化を行なった本システムについて，物理 的特性，撮影技術上の問題点を示し，中耳内耳等複雑な 骨構造の情報量は多くなると評価。今後X線渐屏像と相 補う形で骖断が行なわれるだるうと示唆した。

\section{治療-1 照射法}

座長 植田俊男（愛知県がんセンター）

\section{3. $26 \mathrm{Mev}$ ベータトロン電子線による不均等分割照射 法の経験}

賐河台日本大学病院放射線科 伊藤敏夫 · ○久保田三平・高間良夫

電子線不均等分割照射法は，治療初日を金矅日に設定 し，小照射野大線量 500 700 rad を照射する。，日曜 日は照射を休止，月曜日から木曜日までの 4 日間を大照 射野小線量 150〜200 rad 照射とした。この方法で舌癌， 雪肉瘦, リシパ節転移等の治療を実施すると，均等分割 照射法に比べて病巣線量が12〜15\%増加するととが出来， また正常組織に対しては，被曝線量が12１5\%減少させ ることが出来た。よって放射線治療效果が向上した。不 均等分割照射法は，大線量を照射するため位置決め， 固定等の再現性を正確にするため，舌鉗子，モデりング 等を患者に合せて作製した。なお，線量は毎日，線量分 布仗每月，定期的に測定，較正を実施している.

\section{4. 術中照射に関する検討（第 3 報）胆道系及び肝門部}

術中照射における Absorber (Mix-R) について

筑波大学附属病院

○森 㴊彦: 片岡久雄・千葉 登 小鴨義淌

胆道亲・肝門部術中照射においては，切除病巣に臨接 して切除不能な重要血管が存在する.そこで 1) 腫湯に $2,500 \sim 3,000 \mathrm{rad}$ 照射したい.2）切除不能な重要血管 の前方にある外科的切除の限界を超えて残存する微少病 紧に $1,500 \sim 2,000 \mathrm{rad}$ 照射したい。３）しかも重要血管 に対する被曝線量を最少限にしたい，4) 重要血管に対 する血流阻嗐を緩和したい. 以上の条件を基本的に満足 する Absorber として Mix-R が最道である。 そとで今 回は，術中照射に拈して Absorber 乙してMix-Rを使 用した臨床経験及び12，16，20 Mev Electrons と MixR の厚さの変化によるTumor Dose, Microscopical Tumor Dose 及び重要血管の被曝線量について検討した。

\section{5. 不均等分割照射法の基礎的実験}

\section{京都大学医学部附属病院放射線部 \\ ○湯川1 嚳・房常朋視・西台武弘 \\ 野原弘基・米田和夫}

第 1 報，第 2 報で tumor control rate, delay time を 用いて，不均等分割照射の方が均等分割照射よりあ優れ ている事を示した。皇れで今回はその原因を調べる為， 腫湯移植後，日数と共に腫湯欰管がとのように変化する かを microangiogram, microscopic slideをむちいて調 らべた。その結果 tortuosity 及び hypervascularity は移 植後 4日ではっきりと見られるが管腔の irregularity は 11日目まで見られなからた。 又, pooling, sinusoidal space は腯煬が直径約 $6 \mathrm{~mm}$ ぐらいになった移植後16日 目ぐらいに表われた.今後，照射線量の変化と共に血管 がどう変化するかを調らべてみる。

\section{6. 加温療法における温度測定の検討 熱電対による基 礎的実験}

大阪市立大学医学部附属病院中央放射線部

泉 昭生・伊藤敬三・小野正夫 椎崎信彦・过 政代·木村俊彦 光由宸雄

自家製 $\mathrm{C}-\mathrm{C}$ 熱電対を用い $2,450 \mathrm{MHz}$ マイク口波加温 中の温度測定を行った。測温部は工業用素線 $0.08 \mathrm{~mm} \phi$, を使用，裸熱電対を血管造影用ポリエレンカテーテル 及び金属針內にエポキシ樹脂で封じた：起電力特性は30 $-50^{\circ} \mathrm{C}$ 間は值線. $0^{\circ} \mathrm{C}$ 加 $42.5^{\circ} \mathrm{C}$ の温度変化付対す立 上りは 2 秒以下，製品間のバラッキは土0.1대であ った。金属針に封じたものは発熱があり, hot spot が認 